\title{
Aedeagus Morphology as a discriminant marker in two closely related Cactophilic Species of Drosophila (Diptera; Drosophilidae) in South America
}

\author{
FERNANDO F. FRANCO ${ }^{1}$, PEDRO R.R. PRADO ${ }^{1}$, FÁBIO M. SENE ${ }^{1}$, \\ LUCIANO F. COSTA ${ }^{2}$ and MAURA H. MANFRIN ${ }^{3}$ \\ ${ }^{1}$ Universidade de São Paulo, Faculdade de Medicina de Ribeirão Preto, Departamento de Genética, \\ Bloco A, Av. dos Bandeirantes 3900, 14049-900 Ribeirão Preto, SP, Brasil \\ ${ }^{2}$ Cybernetic Vision Research Group, Instituto de Física de São Carlos - USP \\ Av. Trabalhador são Carlense 400, Cx. Postal 369, 13560-970 São Carlos, SP, Brasil \\ ${ }^{3}$ Departamento de Biologia, Faculdade de Filosofia Ciências e Letras de Ribeirão Preto - USP, \\ Av. dos Bandeirantes 3900, 14040-901 Ribeirão Preto, SP, Brasil
}

Manuscript received on December 12, 2004; accepted for publication on August 19, 2005; contributed by FÁBIO M. SENE*

\begin{abstract}
Drosophila serido and D. antonietae are sibling species belonging to the Drosophila buzzatii cluster. Morphologically, they can only be discriminated by quantitative traits. In this paper we analyze the length and equalized average curvature of four regions of the aedeagus of $D$. antonietae and $D$. serido. Specimens of $D$. serido and D. antonietae were classified correctly $96.74 \%$ of the time. Based only on the variable that most contributed to the discrimination of the groups (equalized average curvature of the arch IV of the aedeagus), we observed significant intraspecific morphological divergence in D. serido in relation to the D. antonietae, in agreement with other markers. The high morphological divergence in equalized average curvature of the arch IV of the aedeagus shows that this region evolved faster than others, since the divergence of the two species. The importance of the present study to the understanding of the genetic basis that controls the formation of the aedeagus, in the species of the Drosophila buzzatii cluster, is discussed.
\end{abstract}

Key words: morphometric, curvature, Drosophila buzzatii cluster, aedeagus.

\section{INTRODUCTION}

Morphological characters have been used historically in evolutionary and taxonomic studies. Nevertheless, the lack of qualitative morphological differences among sibling species makes it difficult to establish the diagnostic morphological characteristics among them. In many cases, quantitative variations of morphometric traits are sufficient to the discrim-

*Member Academia Brasileira de Ciências Correspondence to: Dr. Fábio de Melo Sene E-mail: famesene@usp.br ination of sibling species (Moreteau et al. 2003, Moraes et al. 2004).

The morphology of the aedeagus (external male genitalia) is of extreme importance in the taxonomic characterization of Drosophila species (Vilela 1983, Silva and Sene 1991, Liu et al. 1996, Moreteau et al. 2003, Kullikov et al. 2004), as well as in other Diptera. Quantitative variations in morphological characteristics of the aedeagus have also been used for discrimination of the sibling species of Drosophila (Silva and Sene 1991, Kullikov et al. 
2004). In the Drosophila repleta group, which includes more than 90 Neotropical species, most are considered sibling species. However, a marked difference exists in the aedeagi form (shape + size) among them, which is considered the main diagnostic character in the group (Vilela 1983).

The Drosophila buzzatii cluster (repleta group, mulleri subgroup, buzzatii complex) is a monophyletic group formed by seven sibling cactophilic species: D buzzatii, D. borborema, D. koepferae, D. antonietae, D. gouveai, D. serido and D. seriema. In this cluster, quantitative differences of the morphological characteristics of the wing (Moraes et al. 2004) and male genitalia (Silva and Sene 1991, Tidon-Sklorz and Sene 1995, Prado et al. 2004) have been successfully used for the discrimination of species and populations. Among the seven species of this cluster, D. buzzatii and D. borborema present aedeagi that are different in shape and size from the other species (Tidon-Sklorz and Sene 1995). However, the aedeagus morphology of the other species of the cluster is similar to the so-called D. serido aedeagus type (Figure 1a) and based on this observation, these species were initially classified as belonging to the same species (Vilela and Sene 1977). To study the aedeagus of these species, Silva and Sene (1991) divided it into four main regions delimited by landmarks (Figure 1b). Each region delimited by two adjacent landmarks was denominated arch. Based on the length of the arches, the researchers identified five different types of aedeagus, named from A to E, specific for each species.

Drosophila serido and D. antonietae are two sibling species belonging to the Drosophila buzzatii cluster analyzed in this study. D. antonietae occurs in mesophilic forests in the regions of the ParanáParaguay basin, in South America, associated with the Cereus hildemannianus cactus (Tidon-Sklorz and Sene 2001). D. serido is present in the Northeastern Caatinga and Atlantic Coast of Brazil, from the Northeast to the Southern region of Brazil, associated with a series of cacti genera (Pereira et al. 1983). In the southern limit of the D. serido dis- tribution, there is an area of contact with $D$. antonietae (A.C. Morales et al., unpublished data). Even though D. serido and D. antonietae present distinct metaphasic plates (Baimai et al. 1983), alloenzymatic patterns (A.C. Morales et al., unpublished data, Mateus and Sene 2003), mitochondrial haplotype (Manfrin et al. 2001) and satellite DNA (Kuhn and Sene 2005), they share the same fixed chromosomal inversion $2 \mathrm{x}^{7}$ (Ruiz et al. 2000), which may indicate a closely phylogenetics relationship. In morphological terms, only quantitative variations can discriminate these two species (Silva and Sene 1991, Moraes et al. 2004).

In this paper, morphometrical characters of the aedeagus of $D$. antonietae specimens from several different populations were analyzed, covering all the known distribution of the species, and of $D$. serido specimens coming from two different populations. We have chosen these species because they can be differentiated through genetic markers and, by presenting a secondary contact area, with a population in sympatry, with possible formation of hybrids in the southern region of Brazil. Besides the measurements of length of the arch of the aedeagus, already used in Silva and Sene (1991), curvature measurements of these arches were also used (Prado et al. 2004). Our main objectives were to introduce and test the use of the measures of curvature in the species of the Drosophila buzzatii cluster and to determine the regions of the aedeagus that most contributed to the discrimination of the species $D$. serido and $D$. antonietae. The data discussed here highlight the importance of these regions of the aedeagus for future research in order to understand the genetic basis of the aedeagus of the species belonging to the Drosophila buzzatii cluster, as well as for studies of the area of contact between the two species.

\section{MATERIALS AND METHODS}

\section{SAMPLES}

Fifty-eight aedeagi were analyzed from $D$. antonietae species from several different populations, representing the entire distribution, and 34 aedeagi 


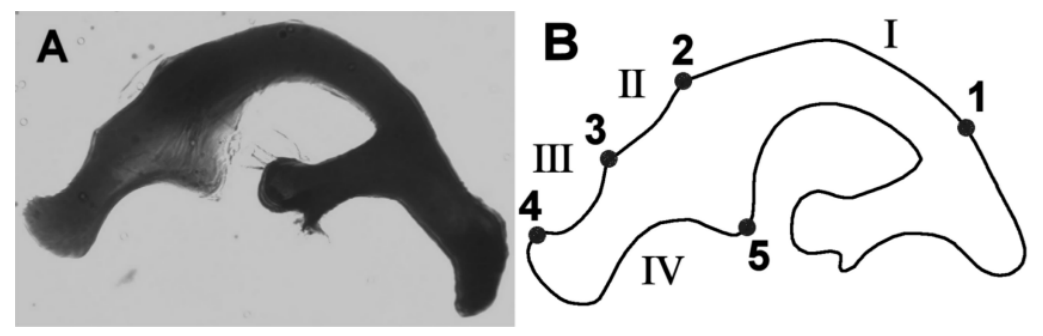

Fig. 1 - A. Aedeagus of a Drosophila antonietae specimen (magnified 200X), that represents the aedeagus form which is shared among D. serido, D. antonietae, D. gouveai, D. seriema and D. koepferae (Silva and Sene 1991). B. Delimitation through landmark, according to Silva and Sene (1991), of the regions analyzed in this work. 1-5 = landmark; I-IV = regions between two adjacent landmark denominated arches.

of $D$. serido, belonging to populations located in Junco do Seridó/PB and Milagres/BA (type localization) (Table I). All the individuals analyzed were collected in natural environments (wild-caught flies). The aedeagi were prepared in slices for optic microscopy according to Kaneshiro (1969). All aedeagi used in this paper were deposited in the Evolutive Genetics Laboratory at USP - Ribeirão Preto. The images of the aedeagi were magnified 200X and digitalized from a microscope (Axioplan2 Zeiss) equipped with the Axiovision Zeiss digital image capturing system and stored on a computer.

\section{MeAsurement and Statistical AnAlysis}

Five points were defined manually as landmarks, according to Silva and Sene (1991). The landmarks were used to establish the internal outlines of the region under study; the regions between two adjacent landmarks are the arches (Figure 1b).

As in Silva and Sene (1991), the length of the arches I, II, III and IV of the aedeagus were measured (Table II). This measures the distance accumulated between the consecutive landmarks. Besides this, we also performed equalized measures of curvature of the arches. In brief, the continuous curvature is a geometric measure that expresses the rate of change of the angle between the tangent of the curve and the axis x (Costa et al. 2004). The values of the equalized curvature are generated through standardization by a sigmoid of the continuous cur- vature to amplify the points of low curvature of the region of interest (Costa and Cesar 2000). This stage allows maximization of the information about the curvature of the structure analyzed. In order to perform the analyses, we used the averages of the equalized curvatures of the arches I, II, III and IV of the aedeagus (Table II). The measures were attained in accordance with the methodology described by Prado et al. (2004).

We performed three distinct discriminant analyses, solely using the measures of length of the arch (discriminant I) and the equalized average curvature (discriminant II) and a discriminant analysis using all the measures together (discriminant III). These analyses were performed to obtain correct percentages of classification of individuals, to verify which variables contributed more to the discrimination of the groups and to compare the use of measures of curvature used with the measures of the length of the arch, previously performed by Silva and Sene (1991). The lower values of Wilk's lambda (which vary from 0 to 1 ) indicate a better analysis. Besides this, with the data from the discriminant analysis III, an analysis of canonic variables was performed. The discriminant and canonical variables analysis was performed with the use of the software Splus (version 1.8).

The absolute value of the canonical standardized coefficients, generated by the analysis of canonical variables, represent the weight of each vari- 
TABLE I

Sample number of individuals of $D$. serido and $D$. antonietae and their respective collection sites.

\begin{tabular}{l|l|c|c|c}
\hline Species & Locality & Geographic Coordinates & Locality Code & Sample $^{o}$ \\
\hline Drosophila serido & Milagres/BA & $12^{\circ} 51^{\prime} \mathrm{S}, 39^{\circ} 53^{\prime} \mathrm{W}$ & $\mathrm{J} 92$ & 22 \\
\hline & Junco do Seridó/PB & $7^{\circ} 00^{\prime} \mathrm{S}, 36^{\circ} 43^{\prime} \mathrm{W}$ & $\mathrm{A} 3$ & 12 \\
\hline Drosophila antonietae & Sertãozinho/SP & $21^{\circ} 10^{\prime} \mathrm{S}, 48^{\circ} 05^{\prime} \mathrm{W}$ & $\mathrm{H} 34$ & 4 \\
\hline & Bocaina/SP & $21^{\circ} 01^{\prime} \mathrm{S}, 47^{\circ} 18^{\prime} \mathrm{W}$ & $\mathrm{H} 88$ & 6 \\
\hline & Serrana/SP & $21^{\circ} 26^{\prime} \mathrm{S}, 47^{\circ} 30^{\prime} \mathrm{W}$ & $\mathrm{H} 84$ & 6 \\
\hline & Sapopema/PR & $23^{\circ} 50^{\prime} \mathrm{S}, 51^{\circ} 45^{\prime} \mathrm{W}$ & $\mathrm{J} 15$ & 7 \\
\hline & Itirapina/SP & $22^{\circ} 16^{\prime} \mathrm{S}, 47^{\circ} 48^{\prime} \mathrm{W}$ & $\mathrm{J} 9$ & 3 \\
\hline & Cambreúva/SP & $23^{\circ} 21^{\prime} \mathrm{S}, 47^{\circ} 20^{\prime} \mathrm{W}$ & $\mathrm{H} 16$ & 8 \\
\hline & Rio Ligeiro/PR & $23^{\circ} 37^{\prime} \mathrm{S}, 52^{\circ} 31^{\prime} \mathrm{W}$ & $\mathrm{D} 93$ & 8 \\
\hline & Santiago-Jaguari/RS & $29^{\circ} 25^{\prime} \mathrm{S}, 54^{\circ} 45^{\prime} \mathrm{W}$ & $\mathrm{H} 47 / \mathrm{H} 46$ & 15 \\
\hline
\end{tabular}

TABLE II

List of measures of the aedeagus performed in the work.

\begin{tabular}{l|c}
\hline \multicolumn{1}{c|}{ Measures } & Abbreviations \\
\hline Length of arch I & AL I \\
\hline Length of arch II & AL II \\
\hline Length of arch III & AL III \\
\hline Length of arch IV & AL IV \\
\hline Equalized average curvature of arch I & MKE I \\
\hline Equalized average curvature of arch II & MKE II \\
\hline Equalized average curvature of arch III & MKE III \\
\hline Equalized average curvature of arch IV & MKE IV \\
\hline
\end{tabular}

able in the formation of the canonical root, where higher values correspond to the most differentiation among groups. These coefficients will be presented to show the relative contribution of each variable in the formation of the canonical root obtained and to determine which variable is most important for the discrimination of the groups.

Besides the multivariate analysis, the most important measure for discrimination of the species was used individually in order to obtain the correct percentage of classification of the individuals through the Bayesian classification method (Duda et al. 2000). For that, normal curves were established from the average and standard deviation of each group in relation to the variable, defining function density and probability used in the Bayesian analysis.

\section{RESULTS}

The results of the three discriminant analyses performed are shown in Table III. The discrimination between $D$. antonietae and $D$. serido is higher when aedeagus arch lengths are used along with the measures of curvature (discriminant III) (Wilks' $\lambda=$ $0.27797 ; \mathrm{p}<0.00001$ ), where $96.74 \%$ of the individuals are classified correctly (Table III), the correct classification of D. antonietae is $98.30 \%$ and of $D$. serido is $94.10 \%$.

Only one canonic axis was obtained in the analysis of the canonic variables using the measures of discriminant analysis III. The canonical standardized coefficients (the weight of each variable) are show in Table IV. The absolute values of these coefficients indicate that the most important variable 
TABLE III

Values of Wilks' $\lambda$ and percentage of correct classification attained by discriminate analysis performed in this work.

\begin{tabular}{c|c|c|c|c}
\hline & Measures Used & Wilks' $\lambda$ & $\mathrm{p}$ & Correct (\%) \\
\hline $\begin{array}{c}\text { Discriminant } \\
\text { analysis I }\end{array}$ & AL I, AL II, AL III e AL IV & 0.56619 & $\mathrm{p}<0.00001$ & 84.80 \\
\hline $\begin{array}{c}\text { Discriminant } \\
\text { analysis II }\end{array}$ & MK I, MK II, MK III e MK IV & 0.42886 & $\mathrm{p}<0.00001$ & 89.13 \\
\hline $\begin{array}{c}\text { Discriminant } \\
\text { analysis III }\end{array}$ & $\begin{array}{c}\text { AL I, AL II, AL III, AL IV, } \\
\text { MK I, MK II, MK III e MK IV }\end{array}$ & 0.27797 & $\mathrm{p}<0.00001$ & 96.74 \\
\hline
\end{tabular}

for the formation of the canonical root was MKE IV while the least important was the variable MKE I. Normal curves obtained by the average and standard deviation of the two groups in relation to the canonical scores are shown in Figure 2, in which we can observe the discrimination between $D$. antonietae (higher canonical scores) and D. serido (lower canonical scores).

\section{TABLE IV}

Standardized canonical coefficients for each variable.

\begin{tabular}{c|c}
\hline Variable & Canonical Root 1 \\
\hline MKE I & 0.078 \\
\hline MKE II & 0.161 \\
\hline MKE III & 0.426 \\
\hline MKE IV & 0.646 \\
\hline AL I & -0.586 \\
\hline AL II & 0.558 \\
\hline AL III & -0.112 \\
\hline AL IV & -0.285 \\
\hline
\end{tabular}

The values for each individual obtained from the analysis of MKE IV are shown in Figure 3a. In relation to this measure, $D$. serido has higher variation around the average (standard deviation $=0.04$ ) than $D$. antonietae (standard deviation $=0.025$ ) (Figure $3 \mathrm{~b}$ ), mainly because there are significant differences in relation to this measure between both populations that compose the sample of D. serido (Figure 3a; Figure 4).

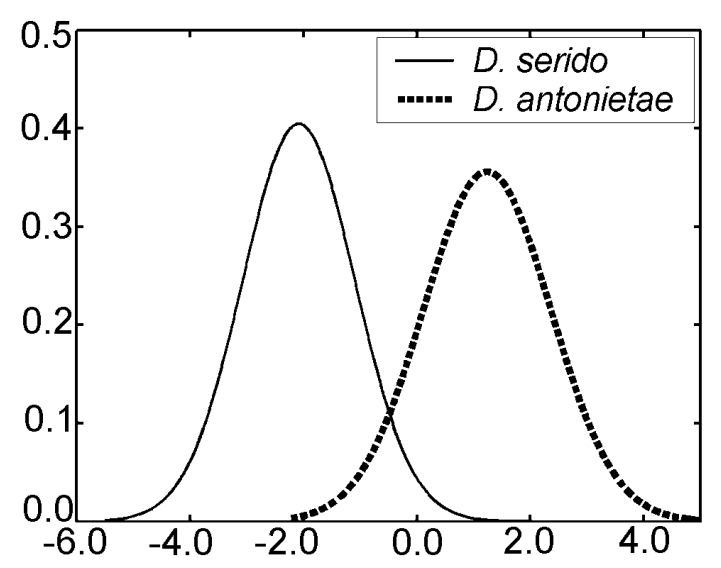

Fig. 2 - Normal curves representing the distribution of the individuals of $D$. antonietae and $D$. serido in relation to the canonic scores.

In accordance with the Bayesian analysis, based only on the MKE IV measure, $69.8 \%$ of the individuals were classified correctly and over $90 \%$ of the individuals of $D$. serido from Milagres/BA were classified correctly. Nevertheless, a high percentage of mistakes were observed in the individuals of the $D$. serido from Junco do Seridó/PB and D. antonietae (Table V). The same analysis was performed without the individuals of $D$. serido from Junco do Seridó/PB and the percentage of correct classifications was $94.83 \%$ (Table VI), showing extreme divergence between the individuals of the population of $D$. serido from Milagres/BA and $D$. antonietae based on MKE IV. 

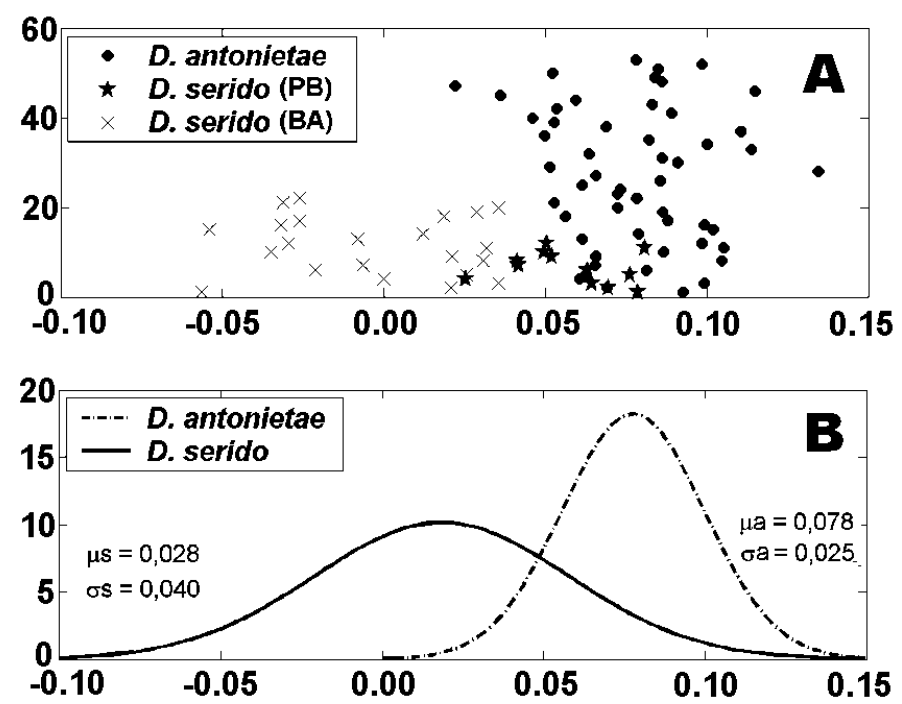

Fig. 3 - A. Graph showing the distribution of the individuals of D. antonietae, D. serido (Junco do Seridó/PB) and D. serido (Milagres/BA) in relation to MKE IV values. B. The Normal curves generated from the average and standard deviation of individuals of $D$. serido and $D$. antonietae in relation to the MKE IV values. $\mu \mathrm{s}=$ average value of MKE IV from individuals of $D$. serido. $\mu \mathrm{a}=$ average value of MKE IV from individuals of $D$. antonietae. $\sigma \mathrm{s}=$ standard deviation for MKE IV in D. serido. $\sigma \mathrm{a}=$ standard deviation for MKE IV in D. antonietae.

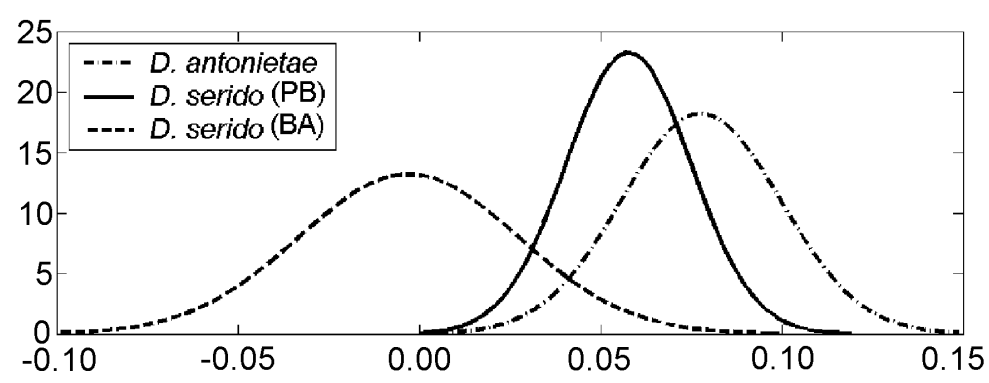

Fig. 4 - Normal curves generated from the average and standard deviation of the groups represented by the individuals of $D$. antonietae and of the individuals of the $D$. serido belonging to populations from Milagres/BA and Junco do Seridó/PB, in relation to the values of the MKE IV measures.

\section{DISCUSSION}

Our data confirm the existence of quantitative differences in morphological characteristics of the aedeagus of the individuals analyzed, making possible the discrimination of the $D$. serido from $D$. antonietae. Furthermore, the equalized average cur- vature of arch IV (MKE IV) was the variable that most contributed to the discrimination of the groups (Table IV).

The length of the first four arches of the aedeagus had already been used with success in the discrimination of species of the Drosophila buzzatii cluster, including among them $D$. serido and $D$. an- 


\section{TABLE V}

Classification of the specimen based on the values of MKE IV. A = D. antonietae. $\mathrm{B}=$ Junco do Seridó/PB population (D. serido). C = Milagres/BA population $(D$. serido $)$.

\begin{tabular}{c|c|c|c}
\hline Group & Correct & Mistake & Correct (\%) \\
\hline A & 30 & 28 & 51.72 \\
\hline B & 8 & 4 & 66.67 \\
\hline C & 20 & 2 & 90.91 \\
\hline Total & 58 & 34 & 69.77 \\
\hline
\end{tabular}

TABLE VI

Classification of the specimens based on the values of MKE IV. A = D. antonietae. $\mathrm{B}=$ Milagres/BA population (D. serido).

\begin{tabular}{c|c|c|c}
\hline Group & Correct & Mistake & Correct (\%) \\
\hline A & 52 & 6 & 89.66 \\
\hline B & 22 & 0 & 100.00 \\
\hline Total & 74 & 6 & 94.83 \\
\hline
\end{tabular}

tonietae (aedeagus Type A and D, respectively in Silva and Sene 1991). In this paper we found a considerable rise in the discrimination of the groups adding measures of equalized average curvature in the morphometric analysis, where $96.74 \%$ of the individuals are correctly classified (Table III). Thus, the measurements of equalized average curvature are important for the discrimination of $D$. antonietae and D. serido and may be useful in the study of a zone of sympatry among these species in the southern region of Brazil. As measures of curvature do not take into consideration the size of the structure, it is possible to infer that small quantitative alterations in the shape of the aedeagus, especially in the region of arch IV, may have occurred since the event of cladogeneses of the $D$. serido and $D$. antonietae species.

There is a significant morphological divergence in relation to MKE IV between $D$. antonietae and $D$. serido, since $D$. antonietae shows relatively less variation around the average than $D$. serido (Fig- ure $3 b$ ). Individuals from different populations, representing the entire distribution area of $D$. antonietae populations (Table I), were analyzed; in this sample, the data suggest that there is homogeneity among the $D$. antonietae populations. Monteiro and Sene (1995) analyzed the morphology of the aedeagus of individuals from several populations of $D$. antonietae through the truss network morphometric method and also did not observe the morphological differences among them. Alloenzymatic (Mateus and Sene 2003) and microsatellites patterns (L.P.B. Machado et al., unpublished data) also showed homogeneity among the different populations of $D$. antonietae. These results suggest gene flow among the populations of $D$. antonietae, favored by the association of this species and its host cactus, Cereus hildmaniannus that occurs in mesophile gallery forests along the rivers of the ParanáParaguay basin, which form corridors of migration for individuals of the species D. antonietae (Monteiro and Sene 1995).

Drosophila serido has, comparatively, a higher interspecific variation in relation to MKE IV than to $D$. antonietae (Figure 3b), as can be observed in the differences found among the individuals from the populations of Junco do Seridó/PB and Milagres/BA. The individuals of $D$. serido from the population of Junco do Seridó/PB have intermediate values for MKE IV of those found for the populations of $D$. serido in Milagres/BA and the populations of D. antonietae analyzed (Figure 4). These data suggest a morphological differentiation between both populations of $D$. serido, probably due to the restriction of the gene flow among them. There is a large river between the Brazilian states of Bahia and Pernambuco, the São Francisco river, which could be acting as a geographic barrier, preventing the gene flow between the populations of $D$. serido analyzed in this paper. Morphological divergences among the populations of $D$. serido are in agreement with other works, being that this species is polytypical in relation to other markers. The northeastern populations of $D$. serido have Type I metaphasic plates, while some coastal populations have Type 
III (Arraial do Cabo/RJ) and Type IV (Peruíbe/SP) metaphasic plates (Baimai et al. 1983). Regarding the chromosomal inversions, although all populations of $D$. serido share the fixed inversion $2 \mathrm{x}^{7}$, four polymorphic inversions are restricted to northeastern populations $\left(2 a^{8}, 2 b^{8}, 2 c^{8}\right.$ and $\left.2 d^{8}\right)$ and two fixed inversions $\left(2 \mathrm{x}^{8}\right.$ and $\left.2 \mathrm{w}^{8}\right)$ occur in coastal populations (Tosi and Sene 1989, Ruiz et al. 2000). Furthermore, the D. serido populations from northeastern Brazil are partially isolated reproductively from the population of Arraial do Cabo/RJ along the Brazilian coast (N.M.V. Bizzo, unpublished data). Recent studies also suggest discrimination among the populations of $D$. serido in the Northeast and coastal Brazil based on differentiation of mitochondrial haplotypes (A.C. Morales et al., unpublished data).

Differentiation among populations of the same species is an important requirement in the process of speciation, thus, studies involving a variety of populations of a polytypical species, such as D. serido, are important in order to quantify the morphological divergence in relation to the genetic divergence in natural populations.

Not all the arches of the aedeagus are equally informative in the discrimination of the species. According to Silva and Sene (1991) arches II and III (Figure 1) are the most informative for the discrimination of the species in the Drosophila buzzatii cluster. In comparison pair-by-pair, using the truss network method, the measures related to arch III were the most significant in the discrimination between D. antonietae and D. gouveai (Monteiro and Sene 1995). Through the analysis of the geometric morphometry using the measures of curvature, Prado et al. (2004) observed that the curvature and the normalized length of arch III are important measures in the discrimination between the D. gouveai and D. antonietae species. Our data show that MKE IV is the most important one in the discrimination of the species $D$. serido and D. antonietae; and based solely on this measure, it is possible to discriminate more than $94 \%$ of the individuals of $D$. serido from the population of Milagres/BA (type localiza- tion) from those of $D$. antonietae (Table VI). These results show that the distal portion of the aedeagus (arch III + arch IV) present the highest interspecific differences, independent from other parts of this organ, suggesting that this region can be considered a "hot evolutionary spot" (Kullikov et al. 2004) for the aedeagus during events of cladogeneses in the Drosophila buzzatii cluster, but this question still remains open for discussion.

The morphometric variations between and within the groups of organisms reflect the expression of a phenotype resulting from an integrated polygenic control, which is altered during cladogeneses and the evolution of groups (Falconer 1989). In addition, several epigenetic and environmental factors can affect the formation of a structure (Atchley et al. 1992), which make it difficult to identify the causes of morphologic divergence among populations and species. Nevertheless, comparative morphometric studies of the homologous regions of both species, such as the arches of the aedeagus, are important requisites for the understanding of the genetic basis that controls the formation of that region. Although the genetic basis of the aedeagus is being discovered for other groups of Drosophila (Liu et al. 1996), the genes that control the formation of the aedeagus in the species of the Drosophila buzzatii cluster are not yet established. The high percentage of correctness of individuals analyzed in this article, based solely on the MKE IV, indicates that the arch four region may be useful for future studies to the understanding of aedeagus genetic basis in these species, since establishing informative morphological characters among distinct taxonomic groups is a preliminary step in the study of QTL (Quantitative Trait Loci), a methodology for the detection, mapping and estimate of effects of some loci in the metric characteristics.

\section{ACKNOWLEDGMENTS}

We would like to thank Prof. Catarina Satie Takahashi and Prof. Elza Tiemi Sakamoto Hojo for making an imaging system available and Prof. 
Evandro M. Mores for reading the manuscript. Work supported by grants from Coordenação de Aperfeiçoamento de Pessoal de Nível Superior (CAPES), Conselho Nacional de Desenvolvimento Científico e Tecnológico (CNPq), Fundação de Amparo à Pesquisa do Estado de São Paulo (FAPESP), Financiadora de Estudos e Projetos (FINEP) and Universidade de São Paulo (USP). We are particularly grateful to anonymous referees for useful critical comments.

\section{RESUMO}

Drosophila serido e D. antonietae são espécies crípticas pertencentes ao "cluster" Drosophila buzzatii. Morfologicamente, elas podem ser discriminadas apenas por diferenças quantitativas. Neste trabalho, nós analisamos o comprimento e a média da curvatura equalizada de quatro regiões do edeago de indivíduos de $D$. antonietae e $D$. serido. Os espécimes de D. serido e D. antonietae foram discriminados com 96,74\% de eficiência. Apenas com base na variável que mais contribuiu para discriminação dos grupos (média da curvatura equalizada do arco IV do edeago), nós observamos significativa divergência morfológica intraespecífica em $D$. serido em relação a $D$. antonietae, o que está em concordância com outros marcadores. A alta divergência morfológica apenas na média da curvatura equalizada do arco IV do edeago mostra que essa região do edeago evoluiu mais rápido que as demais desde a divergência entre as duas espécies. A importância do presente estudo para o entendimento das bases genética que controlam a formação do edeago, nas espécies do “cluster” Drosophila buzzatii, é discutida.

Palavras-chave: morfometria, curvatura, cluster Drosophila buzzatii, edeago.

\section{REFERENCES}

Atchley WR, Cowley DE, Vogi C And McLELLAN T. 1992. Evolutionary divergence, shape change, e genetic correlation structure in the rodent mandible. Syst Biol 41: 196-221.

Baimai V, Sene FM And Pereira MAQR. 1983. Heterochromatin and karyotypic differentiation of some neotropical cactubreeding species of the Drosophila repleta group. Genetica 67: 81-92.
Costa LF AND CESAR RMJ. 2000. Shape analysis and classification: theory and practice. CRC Press Book Series on Image Processing. Cambridge Univ Press, New York, $659 \mathrm{p}$.

Costa LF, dos Reis SF, Arantes RAT, Alves ACR AND Multinari G. 2004. Biological shape analysis by digital curvature. Pattern Recognit 37: 515-524.

Duda RO, HART PE AND Stork DG. 2000. Pattern Classification. J Wiley \& Sons, New York, USA, $680 \mathrm{p}$.

FALCONER DS. 1989. Introduction to quantitative genetics. $2^{\text {nd }}$ ed., London: Longman.

KANESHIRO KY. 1969. A study of the relationships of Hawaiian Drosophila species based on external male genitalia. Univ Texas Publ 6918: 55-70.

KuHN GCS AND SENE FM. 2005. Evolutionary turnover of two pBuM satellite DNA subfamilies in the Drosophila buzzatii species cluster (repleta group): from alpha to alpha/beta arrays. Gene 349: 77-85.

Kullikov AM, Melnikov AI, Gornostaev NG, LAZEBNy OE AND Mitrofanov VG. 2004. Morphological analysis of male mating organ in the Drosophila virilis species group: a multivariate approach. J Zool. Syst Evol Res 42: 135-144.

Liu J, Mercer JM, Stam LF, Gibson GC, Zeng ZhaO-BANG AND LAURIE CC. 1996. Genetic analysis of a morphological shape difference in the male genitalia of Drosophila simulans and D. mauritiana. Genetics 142: 1129-1145.

MANFrin MH, BRito ROA AND SEnE FM. 2001. Systematics and evolution of the Drosophila buzzatii (Diptera; Drosophilidade) cluster using mtDNA. Ann Entomol Soc Am 94: 333-346.

Mateus RP And Sene FM. 2003. Temporal and Spatial Allozyme Variation in the South American Cactophilic Drosophila antonietae (Diptera; Drosophilidae). Biochem Genet 41: 219-233.

Monteiro SG AND SEnE FM. 1995. Estudo morfométrico de populações de Drosophila serido das regiões Central e Sul do Brasil. Rev Bras Genet 18 (Suppl.): 283.

Moraes EM, Spressola VL, Prado PRR, Costa LF AND SENE FM. 2004. Divergence in wing morphology among sibling species of the buzzatii cluster. J Zool Syst Evol Res 42: 154-158. 
Moreteau B, Gibert P, Pétavy G, Moereteau JC, HUEY RB AND DAVID JR. 2003. Morphometrical evolution in a Drosophila clade: the Drosophila obscure group. J Zool Syst Evol Res 41: 64-71.

Pereira MAQR, VIlela CR AND SEne FM. 1983. Notes of breeding and feeding sites of some species of the repleta group of the genus Drosophila (Diptera; Drosophilidae). Cienc Cult 35: 1313-1319.

Prado PRP, Franco FF, Manfrin MH, Costa LF AND SENE FM. 2004. An easy and fast way to analyze morphometric characters. Proc Third Braz Symp Mathem Comp Biol 1: 329-340.

Ruiz A, Cassian AM, Kuhn GCS, Alves Mar AND SENE FM. 2000. The Drosophila serido speciation puzzle: putting new pieces together. Genetica 108: 217-227.

SILVA AFG AND SENE FM. 1991. Morphological geographic variability in Drosophila serido (Diptera; Drosophilidae). Rev Bras Entomol 35: 455-468.
TIDON-SKLORZ R ANd SENE FM. 1995. Evolution of the buzzatii cluster (Drosophila repleta species group) in middle South America. Evolución Biologica 9: 71-85.

Tidon-Sklorz R and Sene FM. 2001. Two new species of the Drosophila serido sibling set (Diptera; Drosophilidae). Iheringia 90: 141-146.

Tosi D AND SEnE FM. 1989. Further studies on chromossomal variability in the complex taxon Drosophila serido (Diptera; Drosophilidae). Rev Bras Genet 12: 729-745.

VILELA CR. 1983. A revision of the Drosophila repleta species group (Diptera; Drosophilidae). Rev Bras Entomol 27: 1-114.

VILELA CR AND SEnE FM. 1977. Two new neotropical species of the repleta group of the genus Drosophila (Diptera; Drosophilidae). Papéis Avulsos de Zoologia 30: 295-299. 